\title{
Vücut Geliştirme Egzersizi Yapan Erkeklerin Ergojenik Yardımcı Kullanma Durumlarına Göre Kaslı Olma Dürtüsü Düzeylerinin İncelenmesi
}

\author{
Haşim KATRA ${ }^{1}$ (D) , Bilgetekin Burak GÜNAR ${ }^{2}$ \\ Nimet Haşıl KORKMAZ ${ }^{3}$ (D) ,Orhan ÖZÇELIK ${ }^{4}$ \\ 'Çanakkale Onsekiz Mart Üniversitesi, Ezine MYO, ÇANAKKALE \\ ${ }^{2}$ Çanakkale Onsekiz Mart Üniversitesi, Spor Bilimleri Fakültesi, ÇANAKKALE \\ 3Uludağ Üniversitesi, Spor Bilimleri Fakültesi, BURSA \\ ${ }^{4}$ Nişantaşı Üniversitesi, Lisansüstü Eğitim Enstitüsü, İTTANBUL
}

Araştırma Makalesi

DOI:10.53434/gbesbd. 1008883

Öz

$\mathrm{Bu}$ araștırmanın amacı vücut geliștirme egzersizi yapan erkeklerin besinsel ergojenik yardımcı kullanma durumuna göre kaslı olma dürtüsü düzeylerinin incelenmesidir. Çalışmaya Çanakkale ilinde

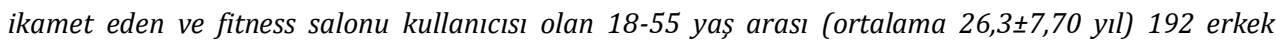
gönüllü olarak katılmıștır. Katılımcılara iki bölümden oluşan anket formu uygulanmıştır. Anketin birinci bölümünde araștırmacılar tarafindan oluşturulan demografik bilgi formu ikinci bölümünde ise McCraery ve Sasse (2000) tarafindan geliştirilen Selvi ve Bozo (2019) tarafindan Türkçe uyarlaması yapılan "Kaslı Olma Dürtüsü Ölçeği" (KODÖ) uygulanmıştır. Araştırmaya dair verilerin analizi SPSS istatistiksel veri analiz programında gerçekleștirilmiştir. Analizilerde gruplar arasındaki ilişkiyi belirlemek amacıyla Pearson Korelasyon, iki grup arasındaki farkı belirlemek için Indepented T Testi ve çoklu gruplar arasındaki farkı belirlemek amacıyla Oneway Anova testleri kullanılmıştır. Çalışma sonucunda katılımcıların \%55,7'sinin besinsel ergojenik yardımcı kullandığı ve bunların içinde en çok tercih edilen takviyelerin ise protein tozu (\%80), dall zincirli amino asit (BCAA) $(\% 55,3)$ ve kreatin $(\% 52,9)$ olduğu görülmüştür. Bununla birlikte besinsel ergojenik yardımcı kullanan katılımcıların istatistiksel anlamda daha yüksek kaslı olma dürtüsüne sahip oldukları tespit edilmiştir $(p<0,05)$. Ayrıca kaslı olmaya yönelik antrenman davranışlarının haftalık egzersiz gün sayısına göre anlamlı farklılık gösterdiği saptanmıştır $(p<0,05)$. Buna karşın kaslı olma dürtüsünün medeni hale göre değişmediği görülmüștür ( $p>0,05)$. Kaslı olmaya yönelik tutumlar ile yaş arasında negatif $(r:-0,194)$, kaslı olmaya yönelik antrenman davranışları (r: 0,261) ve kaslı olmaya yönelik yeme ve takviye kullanımı $(r: 0,253)$ ile antrenman yaşı arasında pozitif yönde anlamlı bir ilişki olduğu bulunmuştur $(p<0,05)$. Bu çalışmada yüksek kaslı olma dürtüsüne sahip bireylerin besinsel ergojenik yardımcı kullanmaya daha fazla eğilimli olduğu ancak bu durumun birtakım riskleri de barındırdı̆̆ı sonucuna ulaşılmıştır.

Anahtar kelimeler : Ergojenik yardımcı, Vücut geliştirme, Kaslı olma dürtüsü 


\title{
Investigation of the Drive for Muscularity among Men Performing Bodybuilding Exercises According to Use of Ergogenic Aids
}

\begin{abstract}
The aim of this research was to investigate the drive for muscularity among men performing bodybuilding exercises according to their use of nutritional ergogenic aids. A total of 192 male volunteers aged from 18-55 years who were gym users residing in Çanakkale province participated in the study. Participants completed a survey form comprising two sections. The first section of the form was a demographic information form created by the researchers, while the second section included the "Drive for Muscularity Scale" developed by McCraery and Sasse (2000) and adapted to Turkish by Selvi and Bozo (2019). Data were analyzed with the SPSS statistical program. Two-way comparisons used the independent groups $t$ test, comparisons between groups used the one-way analysis of variance and mutual correlations used simple linear correlation analysis. As a result of the study, 55.7\% of participants used nutritional ergogenic aids and the most commonly chosen supplements were protein powder (80\%), branch chain amino acids (BCAA) (55.3\%) and creatine (52.9\%). Additionally, participants using nutritional ergogenic aids were identified to have higher drive for muscularity in a statistical sense $(p<0.05)$. Additionally, significant differences were identified according to the number of exercise days weekly in training behavior about muscularity $(p<0.05)$. There were no significant differences for the drive for muscularity subdimensions according to marital status of participants $(p>0.05)$. There was a negative significant correlation between attitudes about muscularity and age $(r=-0.194)$, and positive significant correlations between training age with training behavior for muscularity ( $r=0.261)$ and eating and supplement use for muscularity ( $r=0.253)$. This study concluded that individuals with high drive for muscularity had higher tendency to use nutritional ergogenic aids.
\end{abstract}

Keywords: Ergogenic aid, Bodybuilding, Desire to be muscular

\section{Giriş}

Vücut geliştirme bir kişinin kas kontrolü ve kas gelişimini sağlamak amaciyla direnç egzersizleri uygulaması olarak tanımlanabilir (Emery, 2003). Yalnız ve Gündüz (2004) vücut geliştirmenin estetik kazandırma, kan dolaşımını düzenlemesiyle birlikte solunum kapasitesinde artış sağlama, vücut hakimiyeti, denge ve konsantrasyonu arttırma ve gelişime katkı sağlama gibi birçok yönünden bahsetmiştir. Kaslı olmaya yönelik davranışlar vücut geliştirme sporcularında özellikle erkek sporcularda yaygındır (Chaba, d'Arripe-Longueville, Lentillon-Kaestner ve Scoffier-Mériaux, 2019). Vücut geliştirme erkeklik kimliğinin inşası açısından önemli bir alan olarak değerlendirilmekle birlikte kaslı bir beden yapısına sahip olmayı sağlar (Çarpar ve Şavran, 2019). Vallet (2018) gerçekleştirdiği bir çalışmada vücut geliştirme sporunun tüketim toplumunun normlarını yansıttığı, hoş ve iri bir vücuda sahip olmanın amaçlandığını rapor etmiştir.

Kaslı olma dürtüsü, bireyin yeterince kaslı olmadığı ve vücut kas kütlesini arttırmaya yönelik algısı olarak değerlendirilebilir (McCreary, 2007). Kadınların zayıflık dürtüsü ve erkeklerin kaslı olma dürtüsü kültürel olarak, cinsiyete özgü olabilir ve vücut şekil ideallerini yansıtır (Davis, Karvinen ve McCreary, 2005). Erkeklerin bedensel çekicilik 
standardı vücut yapısının daha büyük, iri ve kaslı olması yönündedir (McCreary ve Sasse, 2000). Erkekler için yağsız kaslı bir vücut şekli geliştirmek merkezi bir sorun haline gelebilir. $\mathrm{Bu}$ vücut yapısını kazanmayı sağlanması için sağlığı tehdit eden sayısız davranışın benimsenmesi endişesini arttırmıştır (Cafri ve diğerleri, 2005).

Çağımızda amatör ya da profesyonel olsun sporcular kaybetmiş oldukları enerjiyi geri almak amacıyla destekleyici besinsel ürünlere yönelmektedir (Argan ve Köse, 2009). Ergojenik yardımcı konusu, sporcuların ilgisini çekmekte, sporcuların beslenmesiyle birlikte antrenmanlarını destek amacıyla kullanılan yöntemlerdendir (Yalnız ve Gündüz, 2004). Birçok ergojenik yardımcı sporcuların sportif performanslarını arttırmak amacıyla kullanılmaktadır (Ahrendt, 2001). Spor bağlamında genel anlamda performansın artırılması için kullanılan bir teknik olan ergojenik yardımcılar (Thein, Thein, Landry, 1998), sporculara rekabet avantajı sağlayabilen maddelerdir (Ahrendt, 2001). Bayram ve Öztürkcan (2020) ergojenik yardımcıların iş üretme ve işin yapılmasına yardım eden maddeler ya da yöntemler olarak açıklanabileceğini sportif performansın arttırılması, toparlanmanın hızlandırılması ve yorgunluğun azaltılması gibi birçok amaçla kullanılabileceğini belirtmişlerdir. Şemşek, Yüktaşır ve Şemşek (2010) besin takviyelerinin sporcular arasında yanlış kullanımının hızla arttığını, Perçinci ve Kıpçak (2020) bu durumun besinsel ergojenik kullanımına yönelik bilgi eksikliğinden kaynaklanabileceğini belirtmişlerdir. Bununla birlikte Çağlayan ve Koz (2020) vücut geliştirme sporuyla ilgilenen bireylerde kas yoksunluğu gibi durumların olabileceğini, bu durumun da ergojenik yardımcı kullanmada bilinçsizlik, aşırı egzersize yönelme gibi durumlarla ilişkili olabileceğini vurgulamışlardır.

Literatürden elde edilen bilgiler ışığında, vücut geliştirme egzersizi yapan bireylerin besin takviyesi alma durumu ile kaslı olmaya yönelik dürtü düzeylerinin belirlenmesi, ergojenik yardımcı kullanma durumlarına göre kaslı olmaya yönelik dürtülerinin karşılaştırılması ve bu iki parametre arasındaki ilişkinin ortaya konması önem arz etmektedir. Bu bilgilerden hareketle bu araştırmada vücut geliştirme egzersizi yapan erkeklerin beslenme takviyesi kullanma durumlarına göre kaslı olma dürtüsü düzeylerinin incelenmesi amaçlanmıştır.

\section{Yöntem}

Bu çalışma Çanakkale Onsekiz Mart Üniversitesi Lisansüstü Eğitim Enstitüsü 29.04.2021 tarih ve 08/14 sayılı etik kurul izin kararıyla gerçekleştirilmiştir.

$\mathrm{Bu}$ çalışma nicel araștırma yöntemlerinden ilişkisel tarama modelinde tasarlanmıştır. Çalışmanın örneklemini kolayda örnekleme ile seçilen 192 gönüllü erkek oluşturmaktadır. Katıllımcılar Çanakkale ilinde faaliyet gösteren fitness merkezlerini kullanan ve 26,3 $\pm 7,70$ yıl yaş ortalamasına sahiptir. Araştırmanın veri toplama süreci 1706-2021 ve 18-07-2021 tarihleri arasında gerçekleştirilmiştir. Araştırmada veri toplama aracı olarak demografik değişkenlere dair bilgi formu ve Kaslı Olma Dürtüsü Ölçeği kullanılmıştır. 
Demografik Bilgi Formu: Araştırmacılar tarafından uzman görüşü alınarak hazırlanan formda katılımcıların yaș, ergojenik yardımcı kullanıp kullanmadıkları, kullandıkları ergojenik yardımcı türü, haftalık egzersiz yapılan gün sayısı, ne kadar süredir vücut geliştirme egzersizi yaptıkları (ay olarak), medeni durumları ve aylık gelirlerine dair sorular bulunmaktadır.

Kaslı Olma Dürtüsü Ölçeği (KODÖ): Ölçek 15 madde ve 3 alt boyuttan (Kaslı Olmaya Yönelik Tutumlar, Kaslı Olmaya Yönelik Antrenman Davranışları, Kaslı Olmaya Yönelik Yeme ve Takviye Kullanma Davranışları) oluşan 6'lı likert tipi ölçektir. Ölçek maddeleri 1 "hiçbir zaman" dan 6 "her zaman"a doğru sıralanmıştır. Ölçekten alınabilecek puan 15-90 arasında değişmekte olup yüksek puan yüksek kaslı olma dürtüsü anlamına gelmektedir. Çalışmada iç tutarlık güvenirliği ise .81 olarak bulunmuştur.

\section{Bulgular}

Çalışmada elde edilen katılımcıların demografik özelliklerine dair ortalama, frekans ve yüzde dağılımları, bağımlı ve bağımsız değişkenlere dair tek yönlü varyans analizi, bağımsız gruplar için t testi, korelasyon analiz sonuçları aşağıda verilmiştir.

Tablo 1. Katılımcıların yaș, vücut geliştirme süresi ve aylık gelirlerine ilişkin veriler

\begin{tabular}{lcccc}
\hline Değișkenler & En az & En fazla & $\overline{\boldsymbol{X}}$ & Ss \\
\hline Yaş & 18 & 55 & 26,3 & 7,70 \\
$\begin{array}{l}\text { Vücut geliştirme süresi } \\
\text { (ay) }\end{array}$ & 1 & 180 & 23,7 & 32,14 \\
Aylık gelir (TL) & 600 & 20000 & 3513,59 & 2961,64 \\
\hline
\end{tabular}

Katılımcıların yaş, vücut geliştirme süresi ve aylı gelirlerine ilişkin veriler Tablo 1'de gösterilmiştir. Araştırmaya katılan bireylerin yaş ortalamasının 26,35 $\pm 7,70$ yıl, vücut geliştirme süresi ortalamasının $23,7 \pm 32,14$ ay ve aylık gelir ortalamasının 3513,59 $\pm 2961,64$ TL olduğu bulunmuştur.

Tablo 2. Katılımcıların medeni durum ve ergojenik yardım kullanma durumlarına ilişkin veriler

\begin{tabular}{llcc}
\hline Değişkenler & Gruplar & f & \% \\
\hline \multirow{2}{*}{ Medeni durum } & Evli & 42 & 21,9 \\
& Bekar & 150 & 78,1 \\
\hline \multirow{2}{*}{ Ergojenik yardım kullanma } & Evet & 85 & 44,3 \\
& Hayır & 107 & 55,7 \\
\hline
\end{tabular}

Tablo 2'ye göre katılımcıların \%78,1 (150)'inin bekar ve \%55,7 (107)'sinin ergojenik yardım kullanmadığı tespit edilmiştir. 
Tablo 3. Kullanılan ergojenik yardımcı içeriğine ilişkin veriler (n:85)

\begin{tabular}{lccllc}
\hline Ergojenik yardımcılar & $\mathbf{f}$ & $\mathbf{\%}$ & Ergojenik yardımcılar & $\mathbf{f}$ & $\mathbf{\%}$ \\
\hline Protein tozu & 68 & 80,00 & Tribulus Terrestiris & 7 & 8,24 \\
BCAA & 47 & 55,29 & CLA & 5 & 5,88 \\
Kreatin & 45 & 52,94 & Termojenik & 3 & 3,53 \\
Multivitamin & 24 & 28,24 & Detox & 3 & 3,53 \\
Glutamin & 21 & 24,71 & AOL & 2 & 2,35 \\
L-Karnitin & 19 & 22,35 & Taurin & 2 & 2,35 \\
Kafein & 18 & 21,18 & Beta Alanin & 2 & 2,35 \\
Ganier & 17 & 20,00 & Nitrik Oksit & 1 & 1,18 \\
Çinko & 15 & 17,65 & Sitrülin Malat & 1 & 1,18 \\
Magnezyum & 15 & 17,65 & Amonyak & 1 & 1,18 \\
Arjinin & 14 & 16,47 & Omega 3 (Balık yağ & 1 & 1,18 \\
Kalsiyum & 10 & 11,76 & & & \\
\hline
\end{tabular}

Tablo 3'e göre katılımcılar tarafından en çok tercih edilen besinsel ergojenik yarımcların protein tozu (\%80), BCAA $(\% 55,3)$ ve kreatin $(\% 52,9)$ olduğu tespit edilmiștir. Bununla birlikte nitrik oksit, sitrülin malat, amonyak ve omega 3'ün birer katılımcı tarafından kullanıldığı görülmüştür.

Tablo 4. Haftalık antrenman gün sayısına göre KODÖ alt boyutlarının karşılaștırılması

\begin{tabular}{|c|c|c|c|c|c|c|}
\hline \multirow[b]{2}{*}{$\begin{array}{l}\text { Haftalık egzersiz } \\
\text { gün sayısı }\end{array}$} & \multicolumn{2}{|c|}{$\begin{array}{l}\text { Kaslı olmaya } \\
\text { yönelik tutumlar }\end{array}$} & \multicolumn{2}{|c|}{$\begin{array}{l}\text { Kaslı olmaya yönelik } \\
\text { antrenman davranışları }\end{array}$} & \multicolumn{2}{|c|}{$\begin{array}{l}\text { Kaslı olmaya yönelik } \\
\text { yeme ve takviye kullanımı }\end{array}$} \\
\hline & $\bar{X}$ & Ss & $\bar{X}$ & Ss & $\bar{X}$ & Ss \\
\hline $1(\mathrm{n}=2)$ & 23 & 12,727 & 10 & 7,071 & 8 & 5,656 \\
\hline $2(\mathrm{n}=6)$ & 26 & 7,874 & 13,83 & 2,786 & 11 & 6,928 \\
\hline $3(n=24)$ & 25,75 & 7,808 & 13,5 & 4,117 & 9,54 & 5,2 \\
\hline $4(n=56)$ & 28,89 & 7,162 & 14,8 & 3,960 & 11,1 & 5,245 \\
\hline $5(n=58)$ & 27,15 & 6,420 & 16,17 & 3,632 & 12,68 & 5,147 \\
\hline $6(n=43)$ & 28,95 & 8,126 & 15,95 & 4,180 & 12,46 & 5,337 \\
\hline $7(\mathrm{n}=3)$ & 32 & 7,31 & 17,66 & 3,055 & 8,33 & 5,859 \\
\hline $\mathrm{F}$ & \multicolumn{2}{|c|}{1,147} & \multicolumn{2}{|c|}{2,598} & \multicolumn{2}{|c|}{1,644} \\
\hline $\mathrm{p}$ & \multicolumn{2}{|c|}{0,337} & \multicolumn{2}{|c|}{$0,019^{*}$} & \multicolumn{2}{|c|}{0,137} \\
\hline $\begin{array}{l}\text { Post-hoc } \\
\text { (Bonferroni) }\end{array}$ & \multicolumn{4}{|c|}{$\begin{array}{c}1<5,1<6,1<7 \\
3<5,3<6\end{array}$} & & \\
\hline
\end{tabular}


Katılımcıların haftalık antrenman yaptıkları gün sayısı ile KODÖ alt boyut puanlarının karşılaştırılması amacıyla yapılan tek yönlü varyans analizi (ANOVA) sonuçları Tablo 4'te gösterilmiştir. Haftalık gün sayısı gruplarında "kaslı olmaya yönelik antrenman davranışları" alt boyutunda gruplar arasında istatistiksel olarak anlamlı fark olduğu belirlenmiştir ( $\mathrm{p}<0,05)$. Bu farkın 1 gün $(10 \pm 7,071)$ ile 5 gün $(16,17 \pm 3,632), 6$ gün $(15,95 \pm 4,180)$ ve 7 gün $(17,66 \pm 3,055)$; 3 gün $(13,5 \pm 4,117)$ ile 5 gün $(16,17 \pm 3,632)$ ve 6 gün $(15,95 \pm 4,180)$ gruplarından kaynakladığı görülmüştür. Buna karşın "kası olmaya yönelik tutumlar" alt boyutu ile "kaslı olmaya yönelik yeme ve takviye kullanımı" alt boyutlarında gruplar arasında anlamlı bir fark bulunamamıştır ( $\mathrm{p}>0,05)$.

Tablo 5. Medeni duruma göre KODÖ alt boyutlarının karşılaştırılması

\begin{tabular}{|c|c|c|c|c|c|c|}
\hline Alt boyutlar & Gruplar & $\mathbf{n}$ & $\bar{X}$ & Ss & $\mathbf{t}$ & $\mathbf{p}$ \\
\hline \multirow{2}{*}{ Kaslı olmaya yönelik tutumlar } & Evli & 42 & 27,78 & 6,315 & \multirow{2}{*}{0,100} & \multirow{2}{*}{0,921} \\
\hline & Bekar & 150 & 27,91 & 7,585 & & \\
\hline \multirow{2}{*}{$\begin{array}{l}\text { Kaslı olmaya yönelik antrenman } \\
\text { davranışları }\end{array}$} & Evli & 42 & 16,04 & 3,975 & \multirow{2}{*}{$-1,411$} & \multirow{2}{*}{0,160} \\
\hline & Bekar & 150 & 15,06 & 4,018 & & \\
\hline \multirow{2}{*}{$\begin{array}{l}\text { Kaslı olmaya yönelik yeme ve takviye } \\
\text { kullanımı }\end{array}$} & Evli & 42 & 12,23 & 6,115 & \multirow{2}{*}{$-0,854$} & \multirow{2}{*}{0,394} \\
\hline & Bekar & 150 & 11,44 & 5,119 & & \\
\hline
\end{tabular}

Katılımcıların medeni durumuna göre KODÖ alt boyutlarının karşılaştırılması amacıyla yapılan bağımsız gruplar için t testi sonuçları Tablo 5 'te gösterilmiştir. Buna göre üç alt boyutta da medeni duruma göre anlamlı bir fark görülmemiştir $(p>0,05)$.

Tablo 6. Ergojenik yardım kullanma durumuna göre KODÖ alt boyutlarının karşılaştırılması

\begin{tabular}{llccccc}
\hline Alt boyutlar & Gruplar & $\mathbf{n}$ & $\overline{\boldsymbol{X}}$ & $\mathbf{S s}$ & $\mathbf{t}$ & $\mathbf{p}$ \\
\hline \multirow{2}{*}{$\begin{array}{l}\text { Kaslı olmaya yönelik tutumlar } \\
\end{array}$} & Evet & 85 & 29,27 & 6,547 & & $0,019^{*}$ \\
& Hayır & 107 & 26,78 & 7,719 & $-2,368$ & \\
\hline $\begin{array}{l}\text { Kaslı olmaya yönelik antrenman } \\
\text { davranışları }\end{array}$ & Evet & 85 & 16,84 & 3,717 & & $0,000^{*}$ \\
\hline $\begin{array}{l}\text { Kaslı olmaya yönelik yeme ve } \\
\text { takviye kullanımı }\end{array}$ & Hayır & 107 & 14,02 & 3,822 & & \\
\hline & Evet & 85 & 15,43 & 4,438 & & $0,000^{*}$
\end{tabular}

Katılımcıların ergojenik yardım kullanma durumuna göre KODÖ alt boyutlarının karşılaştırılması amacıyla yapılan bağımsız gruplar için t testi sonuçları Tablo 6'da gösterilmiştir. Buna göre üç alt boyutta da besinsel ergojenik yardım kullananların (sırasıyla $29,27 \pm 6,547,16,84 \pm 3,717$ ve $15,43 \pm 4,438$ ) puanlarının kullanmayanların (sırasıyla $26,78 \pm 7,719,14,02 \pm 3,822$ ve $8,57 \pm 3,858$ ) puanlarından anlamlı düzeyde yüksek olduğu tespit edilmiştir $(\mathrm{p}<0,05)$. 
Tablo 7. Yaş, vücut geliștirme süresi ve aylık gelir ile KODÖ alt boyutları arasındaki ilişki

\begin{tabular}{lcccccc}
\hline & \multicolumn{2}{c}{$\begin{array}{c}\text { Kaslı olmaya } \\
\text { yönelik tutumlar }\end{array}$} & \multicolumn{2}{c}{$\begin{array}{c}\text { Kaslı olmaya yönelik } \\
\text { antrenman davranışları }\end{array}$} & \multicolumn{2}{c}{$\begin{array}{c}\text { Kaslı olmaya yönelik yeme } \\
\text { ve takviye kullanımı }\end{array}$} \\
\hline Değişkenler & $\mathbf{r}$ & $\mathbf{p}$ & $\mathbf{r}$ & $\mathbf{p}$ & $\mathbf{r}$ & $\mathbf{p}$ \\
\hline Yaș & $-0,194^{*}$ & 0,007 & $-0,047$ & 0,514 & $-0,051$ & 0,483 \\
Vücut geliş̦tirme & $-0,033$ & 0,647 & $0,261^{*}$ & 0,000 & $0,253^{*}$ & 0,000 \\
süresi & $-0,108$ & 0,134 & 0,073 & 0,314 & 0,058 & 0,428 \\
Aylık gelir & & & & &
\end{tabular}

Katılımcıların yaşı, vücut geliştirme süresi ve aylık gelirleri ile KODÖ alt boyutları arasındaki ilişkinin belirlenmesi amacıyla yapılan basit doğrusal korelasyon analizi sonuçları Tablo 7'de gösterilmiştir. Tablo incelendiğinde yaş ile "kaslı olmaya yönelik tutumlar" alt boyutu arasında negatif yönde (r:-0,194), vücut geliştirme süresi ile "kaslı olmaya yönelik antrenman davranışları" ve "kaslı olmaya yönelik yeme ve takviye kullanımı" alt boyutları arasında pozitif yönde (r:0,261 ve r:0,253) anlamlı ilişki olduğu tespit edilmiştir $(p<0,05)$. Buna karşın üç alt boyutun da aylık gelir ile arasında anlamlı bir ilişki olmadığı görülmüştür ( $p>0,05)$.

\section{Tartışma}

$\mathrm{Bu}$ çalışmada vücut geliştirme egzersizi yapan 18-55 yaş arası erkeklerin besinsel ergojenik yardımcı kullanma durumuna göre kaslı olma dürtüsü düzeyleri incelenmiştir. Çalışmada elde edilen veriler vücut geliştirme egzersizi yapan erkek bireylerin ölçüm araçlarına verdikleri yanıtlarla sınırlıdır. Çalışmada incelenen değişkenler demografik özelliklere dair formdan ve Kaslı Olma Dürtüsü Ölçeğinden elde edilen verilerle sınırlıdır.

Veriler incelendiğinde katılımcıların \%55,7'sinin besinsel ergojenik yardımcı kullandığı tespit edilmiştir. Besinsel ergojenik yardımcı kullanan katılımcıların en çok tercih ettikleri ergojenik yardımcı türlerinin sırasıyla protein tozu, BCAA, kreatin ve multivitamin olduğu görülmüştür.

Benzer şekilde Litt ve Dodge (2008) tarafından haltercilerde yapılan bir çalışmada katılımcıların \%30'unun son 6 hafta içinde performans artırıcı madde kullandıkları ve en çok tercih edilen besinsel takviyelerin protein ve kreatin olduğu bulunmuştur. Kreatin, iskelet kasının kasılması için bir enerji substratı olarak hizmet eder. İskelet kası hücreleri, yaklaşık 10 saniyelik yüksek yoğunluklu aktivite için yeterli ATP ve fosfokreatin depolar. Kreatinin takviye olarak alınmasının amacı kaslarda depolanan fosfokreatin düzeyini artırmaktır (Butts, Jacobs ve Silvis, 2018). Kısa süreli kreatin takviyesi, fosfokreatin depolarının \%10 ila \%40 artmasıyla birlikte \%10 ila \%30'luk bir toplam kreatin artışına yol açar (Kreider, 2003; Momaya Fewal ve Estes, 2015).

Ağırlık çalışmaları sırasında da gerekli enerjinin önemli bir bölümü fosfokreatin depolarından karşılanmaktadır. Kreatin takviyesi, kısa süreli, yüksek yoğunluklu egzersizlerde yağsız vücut kütlesini, kuvveti, gücü ve etkinliği artırır (Greydanus ve Patel, 2010). 
Vitaminler ise fiziksel ve zihinsel işlev için gerekli olan enerji üretimi ve anabolik metabolizma dahil olmak üzere birçok hücresel süreçte önemli bir rol oynar (Depeint, Bruce, Shangari, Mehta ve O'Brien, 2006; Yuen ve Sander, 2011). Yapılan çalıșmalar vitamin takviyesinin, yoğun yüklenmeler sırasında karbonhidrat oksidasyonunu ve enerji tüketimini artırabileceğini göstermektedir (Dodd ve diğerleri, 2020; Spriet, 2014) Bu nedenle kreatin ve vitamin takviyeleri vücut geliştirme egzersizlerinde en çok tercih edilen besinsel ergojenik yardımcılar arasında yer almaktadır.

Çağlayan ve Koz (2020) tarafından vücut geliştirme sporu yapan bireylerde yapılan bir çalışmada katılımcıların \%54'ünü ergojenik yardımcıları sık kullandığı \%25'inin ise hiç kullanmadığı tespit edilmiştir. Aynı çalıșmada en çok tercih edilen ergojenik yardımcı türlerinin \%73,4 ile protein tozu, \%70,7 ile BCAA, \%61,3 ile aminoasit ve aynı oranda glutamin olduğu bulunmuştur. Bu sonuçlar çalışmanın bulgularıyla paralellik göstermektedir.

Proteinlerin kas yenilenmesi ve kas hacimdeki artışı sağlayan en önemli besin öğesi olması nedeniyle hem amatör hem de profesyonel sporcular tarafından tercih edildiği düşünülmektedir. Protein ve amino asit takviyeleri, sporcular ve sürekli aktif tüketiciler için kas büyümesi ve performans arttırıcı ürünler olarak yaygın şekilde pazarlanmaktadır ve yüksek proteinli, düşük karbonhidratlı diyetler geleneksel olarak kilo verme amacıyla uygulanmaktadır (Bianco ve diğerleri, 2011; Gannon, Schnuck ve Vaughan, 2018). Sporcular ya da aktif bireyler, hedefe yönelik, sık, yoğun ve/veya uzun süreli egzersiz rutinlerinin çok stresli koşullarında yeterli protein sentezi ve enerji üretiminin yanı sıra yeterli bağışıklık fonksiyonu ve iyi bağırsak bütünlüğünü sürdürmek için yüksek fizyolojik protein gereksinimlerine sahip olabilirler (Kårlund ve diğerleri, 2019).

Atletik bir performansın artan yoğunluğu ve süresi ile protein ihtiyacı da artar. Ancak bilinçsiz protein tüketiminin yol açacağı olumsuz durumların da göz önünde bulundurulması gerekir. Așırı protein tüketiminin hem bağırsak mikrobiyotası hem de konak protein ve amino asit metabolizması üzerinde zararlı etkilere neden olabileceğine ve ayrıca bazı risk popülasyonlarının metabolik sağlığını bozabileceğine dair çalışmalar da vardır(Jang ve diğerleri, 2016; Lee ve diğerleri, 2016).

Bulgular incelendiğinde kaslı olmaya yönelik antrenman davranışları ve kaslı olmaya yönelik yeme ve takviye kullanımının ise vücut geliștirme süresi ile arasında pozitif yönde anlamlı ilișki olduğu yani vücut geliștirme süresinin artmasıyla bu iki bileşenin de arttığı tespit edilmiştir.

Bununla birlikte KODÖ bileșenlerinden kaslı olmaya yönelik antrenman davranışlarının haftalık egzersiz gün sayısına göre anlamlı farklılık gösterdiği ve haftada daha fazla gün egzersiz yapan katılımcıların daha az egzersiz yapan katılımcılara göre daha yüksek kaslı olma dürtüsü puanına sahip oldukları tespit edilmiștir. McCreary ve Sasse (2000) tarafından yapılan bir çalışmada ağırlık antrenmanının sıklığı ile KODÖ puanları arasında pozitif yönlü ilişki olduğu, KODÖ puanları daha yüksek olan katılımcıların düşük olanlara göre daha sık ağırlık antrenmanı yapma eğiliminde olduğu bulunmuştur. $\mathrm{Bu}$ sonuç mevcut çalışmanın bulgularıyla benzerlik göstermektedir. $\mathrm{Bu}$ 
durum kaslı olma dürtüsünün yüksek olduğu durumlarda ağırlık antrenmanlarının daha fazla tercih edilmesiyle açılklanabilir.

$\mathrm{Bu}$ çalışmada ergojenik yardımcı kullanan katılımcıların KODÖ puanının kullanmayanlara göre istatistiksel olarak daha yüksek olduğu görülmüştür. Yani farklı bir ifadeyle kaslı olma dürtüsü düzeyi yüksek olanların besinsel ergojenik yardımcı kullanmaya daha fazla eğilimli oldukları söylenebilir.

Çağlayan ve Koz (2020) tarafından yapılan bir çalışmada kaslı olma dürtüsüne yakın bir konu olan kas yoksunluğu semptomunun da ergojenik yardımcı kullanan vücut geliştirme sporcularında daha yüksek olduğu ortaya konmuştur. Bununla birlikte aynı çalışmada ergojenik yardımcı kullananların kas geliştirme davranışları puanının kullanmayanlara göre istatistiksel anlamda yüksek olduğu bulunmuştur. Bu sonuçlar mevcut çalışmanın bulgularıyla paralellik göstermektedir.

Veriler incelendiğinde kaslı olmaya yönelik tutumlar ile yaş arasında negatif yönde ilişki olduğu yani kaslı olmaya yönelik tutumların yaş arttıkça azaldığı görülmüştür. Nowell ve Ricciardelli (2008) gerçekleștirdikleri bir çalışmada erkek katılımcılar arasında yaşlı bireylerin kaslı olmaya yönelik dürtülerinin zayıf düzeyde olduğunu belirtmişlerdir. Schnelder, Rollitz, Voracek ve Hennig-Fast (2016) çalışmalarında erkeklerin yaş değişkeni ve kaslı olmaya yönelik dürtüleri arasında güçlü bir şekilde negatif yönde illişki olduğunu rapor etmişlerdir.

$\mathrm{Bu}$ sonuçlar mevcut çalışmanın bulgularını desteklemektedir. $\mathrm{Bu}$ durumun genç bireylerin vücut kas kütlesini artırmaya yönelik tutumlarının daha fazla olmasından ve bireylerin yaşın ilerlemesiyle vücut geliștirme egzersizini sağlık parametrelerini korumak ve sürdürmek amacıyla gerçekleștirme ihtimallerinden kaynaklandığı düşünülmektedir.

\section{Sonuç}

Sonuç olarak çalışmada yüksek düzeyde kaslı olma dürtüsüne sahip vücut geliştirme egzersizi yapan bireylerin yüksek oranda besinsel ergojenik yardımcı kullanma eğiliminde oldukları gözlemlenmiştir. Bu nedenle başta protein olmak üzere diğer besinsel ergojenik yardımcıların yapılan egzersizin yoğunluğuna bağlı olarak kişisel gereksinimler doğrultusunda tüketilmesinin optimum düzeyde verim sağlayacağ düşünülmektedir. Bununla birlikte kaslı olma dürtüsü düzeyi üzerinde medeni halin ve aylık gelirin sınırlı bir etkiye sahip olduğu ancak yașın, haftalık egzersiz yapılan gün sayısının ve antrenman yașının daha fazla etkiye sahip olduğu görülmüștür.

Sonuç olarak fitness salonu kullanıcılarının spor eğitmenleri ve diyetisyenler tarafından oluşturulacak programa göre gereksinimleri doğrultusunda takviye kullanmaları, aksi takdirde karşılaşabilecekleri sağlık sorunları hakkında bilgilendirilmeleri önerilmektedir. 


\section{Çıkar Çatışması}

$\mathrm{Bu}$ makalenin yayınlanmasıyla ilgili yazarlar arasında herhangi bir çıkar çatışması bulunmamaktadır.

\section{Yazar Katkıları}

Araştırma Fikri: HK, BBG, NHK, OÖ; Araştırma Tasarımı: HK; Verilerin Analizi: BBG; Makale Yazımı: HK, BBG; Eleştirel İnceleme: HK, BBG, NHK, OÖ

\section{Yazışma Adresi (Corresponding Address):}

Öğr. Gör. Dr. Haşim KATRA

Çanakkale Onsekiz Mart Üniversitesi, Ezine Meslek Yüksekokulu, Çanakkale ORCID: 0000-0002-6271-6114

hkatra@comu.edu.tr 


\section{Kaynaklar}

1. Ahrendt, D. M. (2001). Ergogenic aids: counseling the athlete.American Family Physician, 63(5), 913.

2. Argan, M. ve Köse, H. (2009). Sporcu besin desteklerine (sports supplements) yönelik tutum faktörleri: fitness merkezi katılımcıları üzerine bir araştırma. Spor Bilimleri Dergisi, 20(4), 152-164.

3. Bayram, H. M. ve Öztürkcan, S. A. (2020). Sporcularda ergojenik destekler. Türkiye Klinikleri Sağlık Bilimleri Dergisi, 5(3), 641-652.

4. Bianco, A., Mammina, C., Paoli, A., Bellafiore, M., Battaglia, G., Caramazza, G., Palma, A. ve Jemni, M. (2011). Protein supplementation in strength and conditioning adepts: knowledge, dietary behavior and practice in Palermo, Italy. Journal of the International Society of Sports Nutrition 8(1), 1-6. doi:10.1186/1550-2783-8-25.

5. Butts, J., Jacobs, B. ve Silvis, M. (2018). Creatine use in sports. Sports Health, 10(1), 31-34. https://doi.org/10.1177/1941738117737248.

6. Cafri, G., Thompson, J. K., Ricciardelli, L., McCabe, M., Smolak, L. ve Yesalis, C. (2005). Pursuit of the muscular ideal: Physical and psychological consequences and putative risk factors. Clinical Psychology Review, 25(2), 215-239. doi:10.1016/J.CPR.2004.09.003.

7. Çağlayan, D. ve Koz, M. (2020). Vücut geliştirme sporu ile ilgilenen kişilerde kas yoksunluğu belirtilerinin incelenmesi: Samsun ili örneği. Spormetre Beden Eğitimi ve Spor Bilimleri Dergisi, 18(4), 180-192. doi:10.33689/SPORMETRE.734424.

8. Çarpar, M. C. ve Şavran, T. G. (2019). Beden, kültür ve erkeklik: vücut geliștirmenin eril bir alan olarak savunulması üzerine sosyolojik bir çalışma. Spor Bilimleri Araştırmaları Dergisi, 4(2), 264-288. doi:10.25307/JSSR.629092.

9. Chaba, L., d'Arripe-Longueville, F., Lentillon-Kaestner, V. ve Scoffier-Mériaux, S. (2019). Drive for muscularity behaviors in male bodybuilders: a trans-contextual model of motivation. Journal of Eating Disorders, 7(1), 1-11.

10. Davis, C., Karvinen, K. ve McCreary, D. R. (2005). Personality correlates of a drive for muscularity in young men. Personality and Individual Differences, 39(2), 349-359. doi:10.1016/J.PAID.2005.01.013.

11. Depeint, F., Bruce, W. R., Shangari, N., Mehta, R. ve O'Brien, P. J. (2006). Mitochondrial function and toxicity: role of the $\mathrm{B}$ vitamin family on mitochondrial energy metabolism. Chem Biol Interact, 163(1-2), 94-112.

12. Dodd, F. L., Kennedy, D. O., Stevenson, E. J., Veasey, R. C., Walker, K., Reed, S., Jackson, P. A. ve Haskell-Ramsay, C. F. (2020). Acute and chronic effects of multivitamin/mineral supplementation on objective and subjective energy measures. Nutr Metab (Lond), 17(16), 114. https://doi.org/10.1186/s12986-020-00435-1

13. Emery, M. (2003, Aralık). Men's bodybuilding: A short history. Erişim Adresi: http://www.bodybuildingreviews.net/Bodybuilding.html

14. Gannon, N. P., Schnuck, J. K. ve Vaughan, R. A. (2018). BCAA metabolism and insulin sensitivity - dysregulated by metabolic status? Molecular Nutrition \& Food Research, 62(6), 1700756. doi:10.1002/MNFR.201700756.

15. Greydanus, D. ve Patel, D. (2010). Sports doping in the adolescent: the Faustian conundrum of hors de combat. Pediatr Clin North Am, 57(3), 729-750.

16. Jang, C., Oh, S. F., Wada, S., Rowe, G. C., Liu, L., Chan, M. C., ... Arany, Z. (2016). A branched-chain amino acid metabolite drives vascular fatty acid transport and causes insulin resistance. Nature Medicine, 22(4), 421-426. doi:10.1038/nm.4057.

17. Karakuş, M. (2014). Sporcularda ergojenik destek. Spor Hekimliği Dergisi, 49(4), 155-167. 
18. Kårlund, A., Gómez-Gallego, C., Turpeinen, A. M., Palo-oja, O. M., El-Nezami, H. ve Kolehmainen, M. (2019). Protein supplements and their relation with nutrition, microbiota composition and health: is more protein always better for sportspeople? Nutrients, 11(4), 829. doi:10.3390/NU11040829.

19. Kreider, R. B. (2003). Effects of creatine supplementation on performance and training adaptations. Mol Cell Biochem, 244, 89-94.

20. Lee, C. C., Watkins, S. M., Lorenzo, C., Wagenknecht, L. E., Il'yasova, D., Chen, Y.-D. I., Haffner, S. M. ve Hanley, A. J. (2016). Branched-chain amino acids and insulin metabolism: the Insulin resistance atherosclerosis study (IRAS). Diabetes Care, 39(4), 582-588. doi:10.2337/DC15-2284.

21. Litt, D. ve Dodge, T. (2008). A longitudinal investigation of the Drive for Muscularity Scale: Predicting use of performance enhancing substances and weightlifting among males. Body Image, 5(4), 346-351. doi:10.1016/J.BODYIM.2008.04.002.

22. McCreary, D. R. ve Sasse, D. K. (2000). An exploration of the drive for muscularity in adolescent boys and girls. Journal of the American College Health Association, 48(6), 297-304. doi:10.1080/07448480009596271.

23. McCreary, D. R. (2007). The Drive for Muscularity Scale: Description, psychometrics, and research findings. In J.K. Thompson \& G. Cafri (Eds.), The muscular ideal: Psychological, social, and medical perspectives (pp. 87-106). Washington, DC: American Psychological Association.

24. Momaya, A., Fewal, M. ve Estes, R. (2015). Performance-enhancing substances in sports: a review of the literature. Sports Medicine, 45, 517-531.

25. Nowell, C. ve Ricciardelli, L. A. (2008). Appearance-based comments, body dissatisfaction and drive for muscularity in males. Body Image, 5(4), 337-345.

26. Perçinci, N. B. ve Kibçak, N. (2020). Vücut geliştirme sporu yapan erkeklerin besin desteği kullanim durumlarinin antropometrik ölçümleri ile ilişkisinin değerlendirilmesi. Spor ve Performans Araştırmaları Dergisi, 11(3), 196-206.

27. Schneider, C., Rollitz, L., Voracek, M. ve Hennig-Fast, K. (2016). Biological, psychological, and sociocultural factors contributing to the drive for muscularity in weight-training men. Frontiers in Psychology, 7, 1992.

28. Selvi, K. ve Bozo, 0. (2019). Turkish adaptation of the drive for muscularity scale: a validity and reliability study. Nesne Psikoloji Dergisi, 7(14), 68-82. doi:10.7816/nesne-07-14-05.

29. Spriet, L. L. (2014). New insights into the interaction of carbohydrate and fat metabolism during exercise. Sports Medicine, 44(1), 87-96.

30. Şemşek, Ö., Yüktaşır, B. ve Şemşek, S. (2010). Ergojenik yardimci olarak kullanilan besin suplementleri. Atatürk Üniversitesi BESYO Beden Eğitimi ve Spor Bilimleri Dergisi, 1(3), 7481.

31. Thein, L. A., Thein, J. M. ve Landry, G. L. (1995). Ergogenic aids. Physical Therapy, 75(5), 426-439.

32. Vallet, G. (2014). Mass production'in the mass consumption societies: the case of male bodybuilding. Journal of Literature and Art Studies, 4(3), 208-218.

33. Yalnız, İ. ve Gündüz, N. (2004). Ankara ilinde vücut geliştirme branşında faaliyet gösteren sporcuların ergojenik yardımcılar konusunda bilgi ve uygulama düzeyleri. Gazi Beden Eğitimi ve Spor Bilimleri Dergisi, 9(2), 33-42.

34. Yuen, A. W. ve Sander, J. W. (2011). Impaired mitochondrial energy production: the basis of pharmacoresistance in epilepsy. Med Hypotheses, 77(4), 536-40. 